\title{
O Ensino da Terapia Ocupacional em Contextos Hospitalares: por uma Formação Técnica, Ética, Humanista e Crítica
}

\author{
Braga, Cláudia Pellegrini; Galheigo, Sandra Maria \\ FMUSP — claudia.pellegrini.braga@gmail.com
}

\begin{abstract}
Introdução na formação em terapia ocupacional em contextos hospitalares, faz-se presente o desafio de desconstruir para o estudante a centralidade do 'hospital das especialidades', cujo foco hegemônico é a prática centrada em procedimentos, e recolocar a atenção partir do lugar da produção do cuidado em saúde na perspectiva usuário-centrada, na configuração proposta pelas políticas de saúde. Nessa linha, é preciso possibilitar ao estudante o exercício da leitura das necessidades dos usuários e a apropriação e uso crítico de ferramentas tecnológicas variadas leves, leves-duras e duras -, que deem conta da complexidade do cuidado. a experimentação da prática profissional, orientada pela perspectiva da integralidade e humanização, implica na incorporação de uma sabedoria prática, que acontece no ato de produção das relações e da comunicação estudante-supervisor-usuário. Objetivos Apresentar e refletir sobre o ensino teóricoprático da terapia ocupacional em contextos hospitalares oferecido com vistas a uma formação técnica, ética, humanista e crítica. Métodos Trata-se de relato de experiência, a partir das anotações, experiências e reflexões da supervisora e da docente acerca do ensino teórico-prático da terapia ocupacional em contextos hospitalares. Resultados As atividades práticas foram desenvolvidas em uma enfermaria pediátrica com a população infanto-juvenil e seus familiares/cuidadores. Pela presença implicada do supervisor em sua relação com o estudante, foi possível que o estudante experimentasse e compreendesse que a produção do cuidado acontece nas micro relações entre usuários e terapeuta, usuários e equipe, profissionais das equipes, e nas diferentes ambiências que compõem o cotidiano do serviço. por meio da práxis e da criação de vínculos os estudantes exercitaram as facetas do cuidado, acolhendo as demandas, necessidades, sofrimentos e desejos dos usuários, sustentando as relações, e produzindo projetos terapêuticos e de vida. a experiência de cuidado permitiu aos estudantes o desenvolvimento de uma sabedoria prática, que acontece em resposta aos encontros-acontecimento entre estudantes-supervisorusuários. As atividades de supervisão garantiram um suporte reflexivo a essa experiência da prática. Nessas, exercitava-se a crítica das cenas vividas e das estratégias utilizadas, formulavam-se questionamentos e refletia-se sobre as potencialidades e limites da produção de cuidado em um cenário ainda hoje marcado pelas perspectivas biomédica e especialista. Pela práxis crítica, buscava-se, coletivamente, alternativas práticas para situações vistas como produtoras de violência ou fragilidade para os usuários do serviço. Conclusões Percebe-se que, a partir de uma educação teórico-prática orientada para a práxis e a ética do cuidado e de uma perspectiva crítica em terapia ocupacional, é possível oferecer uma formação profissional em contextos hospitalares voltada para a produção de um cuidado integral e humanizado.
\end{abstract}

Braga, Cláudia Pellegrini; Galheigo, Sandra Maria. O Ensino da Terapia Ocupacional em Contextos Hospitalares: por uma Formação Técnica, Ética, Humanista e Crítica.. In: Anais do Congresso Internacional de Humanidades \& Humanização em Saúde [= Blucher Medical Proceedings, num.2, vol.1]. São Paulo: Editora Blucher, 2014. ISSN 23577282

DOI 10.5151/medpro-cihhs-10695 